\title{
Effect of fertilizer application on the 'Bukhara- 102 ' variety of cotton yield in salt-affected cotton fields of Uzbekistan
}

\author{
$S$ Isaev $^{1, *}, T$ Rajabov ${ }^{2}, G$ Goziev $^{3}$, and $A$ Khojasov $^{4}$ \\ ${ }^{1}$ Tashkent Institute of Irrigation and Agricultural Mechanization Engineers, Kary Niyazi str. 39, \\ Tashkent, 100000, Uzbekistan \\ ${ }^{2}$ Karshi Engineering Economic Institute, Mustakillik str. 225, Karshi, Kashkadarya province, 180100 , \\ Uzbekistan \\ ${ }^{3}$ Ministry of Innovative Development of the Republic of Uzbekistan, University str., 7, Tashkent, \\ 100174, Uzbekistan \\ ${ }^{4}$ Nukus branch of Tashkent State Agrarian University, Abdanbetova str, Nukus, Republic of \\ Karakalpakstan, 230109, Uzbekistan
}

\begin{abstract}
In this article, stratified feeding of Bukhara-102 variety of medium-fiber cotton with mineral fertilizers were carried out in the conditions of irrigated and fertile soils of Kashkadarya province. Simultaneously, compared to the studied fertilizer application options, there was a decrease in soil volume by $0.01-0.02 \mathrm{~g} / \mathrm{cm} 3$, an increase in soil porosity by $0.4-1.2 \%$, and an increase in soil water permeability to $5.8-$ $24.6 \mathrm{~m} 3 / \mathrm{ha}$. Moreover, an additional yield of 1.3-2.6 quintals of cotton, the quality indicators of fiber length that increased by $0.1-0.2 \%$, fiber yield to $0.2-0.5 \%$, the weight of 1,000 seeds to $1-2$ grams , the incidence of Wilt's disease was found to become as low as $6.1-10 \%$. At the same time, with increasing salinity in the care of saline soils at different levels, the net profit was around $40,617-1,127,853$ UZS and the profitability rate was $0.8-20.1 \%$ lower than expected.
\end{abstract}

\section{Introduction}

Nowadays, there is a total of 240 million hectares of irrigated land in the world, from which 41 million hectares of land is used throughout the year $[1,15]$. The breakdown of the total irrigated land at national level: in China - 31.5\%, India - $27.5 \%$, the USA - 5\%, Russia $3.5 \%$, and Pakistan 3.3\% respectively [2, 15-16]. Besides that, in nine countries such as Argentina, Australia, Bangladesh, Kazakhstan, Myanmar, Thailand, Turkey, Uzbekistan, and Vietnam, $1-2 \%$ of the total worldwide agricultural land is utilized. Only $20.7 \%$ of the 20.2 million hectares of agricultural land in Uzbekistan is irrigated. Over the past 15 years, irrigated land in Uzbekistan has decreased by $24 \%$ per capita from 0.23 to $0.16[3,16]$. Moreover, $44-46 \%$ of the agricultural area is exceptionally vulnerable to soil salinization at different levels $[1-5,17]$.

* Corresponding author: sabirjan.isaev@mail.ru 
Worldwide, such efforts are being made to sustainably manage land, water, fertilizers, and natural non-renewable resources in an integrated manner to ensure high agricultural crop yields that determine optimal feeding regimes for saline soils $[6,8,17]$. One of the most pressurizing issues is the development and implementation of state-of-the-art technologies, which track and trace the changing dynamics of the salt-affected soil conditions of different levels, to protect and conserve land and water resources, fertilizers, and natural resources $[7,12,19]$.

Such sustainable irrigation technologies are widely introduced in Uzbekistan with the use of portable flexible pipes instead of drips, plastic or starch films, and beetled-soilfurrows in the cultivation of agricultural crops [8-10, 22]. As a result, irrigation water is steeply being conserved, land reclamation is moderately improved, groundwater levels are constantly being monitored and reduced, and land productivity is slightly increased [20, 23]. One of the important tasks in the nationwide agricultural sector is indicated in the Presidential Decree of the Republic of Uzbekistan dated October 23, 2019 No PD-5853 "On approval of the agricultural development Strategy of the Republic of Uzbekistan for 2020- 2030 year period". In this regard, scientific research and a number of studies on saving mineral fertilizers and improving the reclamation status of irrigated lands by further improving the cultivation of cotton in the country is of great importance [1-5].

Another Presidential Decree No. 3405 of November 27, 2017 "On the State Program for the Development of Irrigation and Improvement of Irrigated Land Reclamation for 20182019" and the Resolution No. 74 of the Cabinet of Ministers of the Republic of Uzbekistan dated February 2, 2018 "On guaranteed water supply of arable lands in the 2018's vegetation period", and Presidential Resolution No. PR-5742 of July 17, 2019 "On urgent measures to prevent the negative consequences of water shortages and on measures for the efficient use of land and water resources in agriculture" and other normative legal acts serve to a certain extent in the implementation of sustainable irrigation measures in Uzbekistan [2-3].

S. N. Rijov [10], M. P. Mednis, R. Akhmedov S. A. Gildiev, F. M. Sattarov [11], Q. M. Mirzajonov, N. F. Bespalov [14], G. A. Bezborodov [13], B. F. Kambarov, R. K. Ikramov, M. KH. Khamidov, A. E. Avliyaqulov [12], B. S. Mambetnazarov, A. S. Shamsiev, U. Norkulov, S. KH. Isaev [17-20], J. K. Shadmanov, M. M. Hasanov, G. Goziev [15-20] and, as international scientists, D. Balla, S. Maasen, J. Andersson, B. Wedding, K. Toderski, K. M. Keinzler, A. S. Qureshi, M. Kadir, U. Umbetaev, V. P. Afanasev, V. G. Mamatov, Sh. T. Kidane, T. L. Danilova, J. P. Melkulova, V. V. Stuchkov [16-17] and other endless list of local and international scientists have majorly contributed to the study of the impact of a wide range of irrigation methods, procedures, techniques, and technologies on agricultural crops in irrigated agricultural land of Uzbekistan, and brief investigation of the water and physical properties of the soil, soil-crop nutrient regime, plant growth, and crop productivity and its quality.

Despite a number of above-mentioned scientists having contributed to the development of agriculture, still such research activities have to be conducted to develop the efficiency of various application of mineral fertilizers on Bukhara-102 variety of medium-fiber cotton (hereinafter, Bukhara- 102) on salt-affected soils at different levels in Kashkadarya province and to determine the impact of fertilizer application options on soilwater and physical properties, cotton growth and cotton yield.

Therefore, the purpose of this research was to irrigate the Bukhara-102 in the conditions of irrigated barren soils of Kashkadarya province with diverse soil moisture content of 70$70-60 \%$ relative to the limited field moisture content (LMFC). The objectives of this research are following: (1) determining the mechanical composition of the experimental field soil, the moisture content of the field, and the level of nutrient capacity in the soil; (2) ascertaining the effect of applying mineral fertilizers on Bukhara-102 with different levels 
of saline soils (no salinity, weak, and moderate), considering the agrophysical, hydrophysical, and agrochemical properties of the soil; (3) calculating the timing, rate, and water consumption of cotton irrigation when applying mineral fertilizers on different saline soils and developing the water balance of the field; (4) calculating the dry mass and the total amount of N, P, K by taking a plant sample at the end of the growing season from each variant of fertilizer application to determine how much nutrients cotton absorbs from the soil in different saline soils; (5) determining the effect of cotton fertilizer absorption at different levels of saline soils on plant growth and development, and cotton yield; and lastly (6) proposing scientific recommendations for the production of technological quality and economic efficiency of fiber.

\section{Study area}

As the study area, irrigated saline soils of Kashkadarya province at different levels (nonsaline, weak and moderate) (Fig. 1) were selected to examine the growing process of Bukhara-102 when mineral fertilizers were applied in different scales.

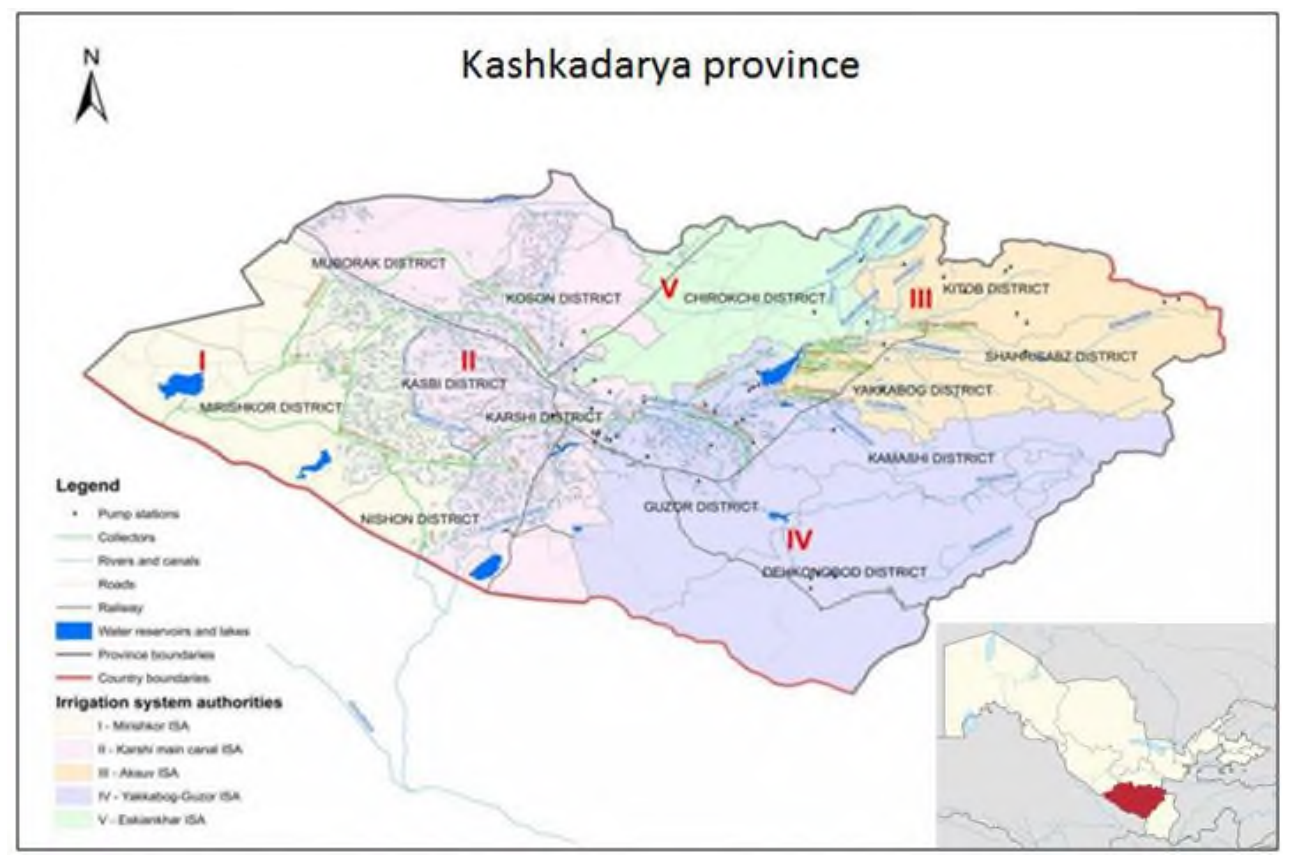

Fig. 1. A spatial location of the study area (source: Djumaboev et al. 2018).

The climate of the Kashkadarya province is moderately continental and at the same time with hot summers and cold winters. The cold winter air in the northern part of the Arctic causes a significant reduction in temperature. In January, average temperatures may drop from $0^{\circ} \mathrm{C}$ to $+2{ }^{\circ} \mathrm{C}$, sometimes from $-15^{\circ} \mathrm{C}$ to $-25^{\circ} \mathrm{C}$ in winter. Summer is hot and dry and lasts for a long time and in July, average daytime air temperatures sometimes range from + $44^{\circ} \mathrm{C}$ to $+47^{\circ} \mathrm{C}$. By the second half of the summer, windy weather dominates and significantly damages agricultural crops. The sum of the average long- term amount of precipitation is: in the plains $290-300 \mathrm{~mm}$; in the hills $320-550 \mathrm{~mm}$; in the mountains 550 $650 \mathrm{~mm}$. Winter and early spring are the precipitation seasons of the study area [21].

The subjective components of research are the cultivation of medium-fiber cotton on different saline soils, irrigation and water consumption of cotton, agrophysical and 
agrochemical properties of soil, cotton growth and development, and cotton yield and its technological quality indicators.

\section{Materials and methods}

Conducting field experiments and all in-situ measurements, observations, and calculations were carried out according to the 'Methods of field experiments' [7-9]. Besides that the analyses were conducted to determine the amount of soil nutrients and vegetation with respect to the 'Methods of agrochemical and agrophysical research in irrigated cotton fields' [4-6]. The primary data derived from the in-situ field work were then analyzed according to Dospekhov's dispersion mathematical-statistical analysis method entitled 'Methodology of field experiment' [7] and Microsoft Excel software.

The experiment consisted of nine options, three iterations, $240 \mathrm{~m}^{2}$ of standard area per each option, and $6480 \mathrm{~m}^{2}$ of the total experimental land area. Bukhara-102 was planted during the experiment and pre-irrigation soil moisture was $70-70-60 \%$ relative to the LFMC. Phenological observations and soil and plant sampling were undertaken at the Scientific Research Institute of Cotton Breeding, Seed Production and Agrotechnology, considering above-listed reference instructive literatures. During the agrochemical analysis in the experimental field, soil sections (incisions) up to $1-1.5 \mathrm{~m}$ were cut in the form of envelopes and soil samples were taken from genetic layers. The amount of humus in the soil (with methods developed by I. V. Tyurin), total nitrogen and phosphorus (with methods developed by A. F. Gritsenko and I. M. Maltseva), and the amount of nitrate nitrogen were determined by the method of Grandvald-Lyaju. Moreover, the amount of reactive phosphorus by the method of B.P.Machigin, the volume mass of the soil by the method of S. N. Rijov (so-called as the cylindrical method), and the soil mechanical composition by the method of I. V. Savvinov were ascertained [7-10, 22-23].

Soil morphological characteristics, soil mechanical composition, soil agrochemical and agrophysical characteristics of the experimental field, this research on the advantages of "Bukhara-102" provided detailed information about differently salt-affected soil moisture, seasonal water norm, groundwater level, nutrient content in the soil, seedling thickness within three experimental years (2010-2012).

\section{Results and discussion}

In the analysis of soil samples from the farmyards, namely "Sunnatov Shahriyor" and "Kurbanov Ilhom Ismatillaevich" in the territory of "SH. Rashidov" Administrative Territorial Division (ATD) in "Kasbi" administrative district, Kashkadarya province, the humus content in the active soil layer $(0-30 \mathrm{~cm})$ was $0.988 \%$, total nitrogen $-0.074 \%$, phosphorus - $0.099 \%$, and in the layer of $30-50 \mathrm{~cm}-$ humus $-0.785 \%$, total nitrogen $0.059 \%$, and phosphorus $-0.084 \%$.

The content of nitrate nitrogen in the soil and cultivating layers was $1.46-3.74 \mathrm{mg}$ per 1 $\mathrm{kg}$ of soil, reactive phosphorus was $17.43-23.35 \mathrm{mg} / \mathrm{kg}$, and exchangeable potassium was $190-210 \mathrm{mg} / \mathrm{kg}$. Hence, it was found that the cultivating layer of the experimental field was very poorly supplied with reactive nitrogen, moderately supplied with reactive phosphorus and exchangeable potassium.

The LFMC of the experimental field soil was $21.3-21.9 \%$ of the absolute dry mass of the soil in the $0-50 \mathrm{~cm}$ layer, $21.6-22.4 \%$ in the $0-70 \mathrm{~cm}$ layer and $22.0-22.8 \%$ in the 0 $100 \mathrm{~cm}$ layer of soil. The soil volumetric mass of the experimental field was determined in all options before the experiment and at the end of the fertilizer application period. 
At the beginning of the first experiment, the results of agrophysical observations in the soil showed that in 2010 on the non-saline soils of the field in the $0-30 \mathrm{~cm}$ layer of soil the volume weight was $1.30 \mathrm{~g} / \mathrm{cm}^{3}$, in $30-50 \mathrm{~cm}-1.40 \mathrm{~g} / \mathrm{cm}^{3}$, and in $0-50 \mathrm{~cm}-1.34 \mathrm{~g} / \mathrm{cm}^{3}$. By the end of the fertilizer application period, as a result of agro-technical measures, the soil volume weight increased by $1.34 \mathrm{~g} / \mathrm{cm}^{3}$ in $0-30 \mathrm{~cm}$ layer of soil, in $30-50 \mathrm{~cm}-1.42 \mathrm{~g} / \mathrm{cm}^{3}$, and $0-50 \mathrm{~cm}-1.37 \mathrm{~g} / \mathrm{cm}^{3}$ in the non-saline part of the field in 2010 , following 1,$37 ; 1,43$; 1,39 in 2011 , and 1,$38 ; 1,43 ; 1,40$ in 2012 respectively. Regarding the weakly saline soils of the experimental field, the results of soil volume weight were 1,$36 ; 1,43 ; 1,39$ in 2010 , following 1,$39 ; 1,44 ; 1,41$ in 2011 , and 1,$40 ; 1,44 ; 1,42 \mathrm{~g} / \mathrm{cm}^{3}$ in 2012 respectively. In regards to the moderately saline soils of the field, there were 1,$38 ; 1,44 ; 1,40$ in 2010 , following 1,$40 ; 1,45 ; 1,42$ in 2011 , and 1,$41 ; 1,45 ; 1,42$ in 2012 respectively. In the further years of the experiment the same patterns were maintained.

Soil water permeability in the non-saline field for six hours in $2010-800 \mathrm{~m}^{3} / \mathrm{ha}$, in 2011 $-730.0 \mathrm{~m} 3 / \mathrm{ha}$, in $2012-690 \mathrm{~m}^{3} / \mathrm{ha}$, in the weakly saline field $-750 \mathrm{~m}^{3} / \mathrm{ha}$ in 2010 , in 2011 - $640.0 \mathrm{~m}^{3} / \mathrm{ha}$, in $2012-630.0 \mathrm{~m}^{3} / \mathrm{ha}$, and in the moderately saline field $-2010-710 \mathrm{~m}^{3} / \mathrm{ha}$, in $2011-610.0 \mathrm{~m}^{3} / \mathrm{ha}$, in $2012-580 \mathrm{~m}^{3} / \mathrm{ha}$.

At the beginning of the 2010 period in the non-saline field where the experiment was settled, the total nitrogen content was $0.076 \%$ at $0-30 \mathrm{~cm}, 0.063 \%$ at $30-50 \mathrm{~cm}, 0.070 \%$ at $0-50 \mathrm{~cm}$, in $2011-0.0740 .041 ; 0.061$ respectively, and in $2012-0.110 ; 0.101 ; 0.106$ respectively; phosphorus in $2010-0.216 ; 0.208 ; 0.221$, in $2011-0.150 ; 0.138 ; 0.145$, and in $2012-0.216 ; 0.200 ; 0.209 \%$ respectively; and the humus content in $2010-0.945 ; 0.857$; 0.909 , in $2011-1,154 ; 0.828 ; 1,024$, and in $2012-1,116 ; 0.916 ; 1,030 \%$ respectively. In the weakly saline field at the beginning of the 2010 period, the total nitrogen content was $0.074 \%$ at $0-30 \mathrm{~cm}, 0.071 \%$ at $30-50 \mathrm{~cm}, 0.072 \%$ at $0-50 \mathrm{~cm}$, in $2011-0.063 ; 0.039 ; 0.053$ respectively, and in $2012-0.094 ; 0.079 ; 0.080 \%$ respectively; phosphorus in $2010-0.224$; $0.208 ; 0.217$, in $2011-0.158 ; 0.144 ; 0.152$, and in $2012-0.094 ; 0.079 ; 0.080 \%$ respectively, humus in $2010-0.945 ; 0.770 ; 0.875$ respectively, in $2011-1,116 ; 0.770$; 0.978 respectively, and in $2012-0.857 ; 0.682 ; 0.754$ respectively. At the beginning of the application period in 2010 , the average nitrogen content in the moderately saline field was $0.046 \%$ at $0-30 \mathrm{~cm}, 0.047 \%$ at $30-50 \mathrm{~cm}, 0.045$ at $0-50 \mathrm{~cm}$, in $2011-0.063 ; 0.039 ; 0.053$ respectively, and in $2012-0.058 ; 0.051 ; 0.055 \%$ respectively; phosphorus in $2010-0.208$ $0.224 ; 0.223$, in $2011-0.164 ; 0.138 ; 0.154$, and in $2012-0.200 ; 0.144 ; 0.177 \%$ respectively; humus in $2010-0.828 ; 0.711 ; 0.731$, in $2011-1,116 ; 0.711 ; 0.954$, and in $2012-0.799 ; 0.682 ; 0.752 \%$ respectively.

In the beginning of the 2010 period in the non-saline field, the amount of nitrate nitrogen from reactive nutrients accounted for $2.40 \mathrm{mg} / \mathrm{kg}$ at $0-30 \mathrm{~cm}, 1.80 \mathrm{mg} / \mathrm{kg}$ at $30-50$ $\mathrm{cm}$, and $2.16 \mathrm{mg} / \mathrm{kg}$ at $0-50 \mathrm{~cm}$, in $2011-0.82 ; 0.70 ; 0.77$ respectively, and in $2012-4.02$; $3.42 ; 3.78 \mathrm{mg} / \mathrm{kg}$ respectively; phosphorus in $2010-8.7 ; 4.5 ; 7.0$ respectively, in 2011 $4.7 ; 0 ; 2.82$ respectively, and in $2012-28.1 ; 11.6 ; 21.5 \mathrm{mg} / \mathrm{kg}$ ha respectively; and potassium in 2010 - 240; 240; 240 respectively, in 2011 - 160; 120; 144, and in 2012 - 160; $140 ; 152 \mathrm{mg} / \mathrm{kg}$ respectively. Moving on to the weakly saline fields, in 2010 , the amount of nitrate nitrogen from reactive nutrients increased to $5.95 \mathrm{mg} / \mathrm{kg}$ at $0-30 \mathrm{~cm}, 2.40 \mathrm{mg} / \mathrm{kg}$ at $30-50 \mathrm{~cm}$, and $4.53 \mathrm{mg} / \mathrm{kg}$ at $0-50 \mathrm{~cm}$, in $2011-2.60 ; 0.70 ; 1.84$ respectively, and in 2012 $4.22 ; 3.82 ; 4.06 \mathrm{mg} / \mathrm{kg}$ respectively; phosphorus in $2010-6.6 ; 4.5 ; 5.7$ respectively, in $2011-4.0 ; 2.5 ; 3.4$ respectively, and in $2012-4.7 ; 0 ; 2.8 \mathrm{mg} / \mathrm{kg}$ ha respectively; potassium in $2010-180 ; 180 ; 180$ respectively, in $2011-160 ; 140 ; 152$, and in $2012-140 ; 120 ; 132$ $\mathrm{mg} / \mathrm{kg}$ respectively. In the moderately saline field, at the beginning of 2010 , the amount of nitrate nitrogen from reactive nutrients was $7.32 \mathrm{mg} / \mathrm{kg}$ at $0-30 \mathrm{~cm}, 1.22 \mathrm{mg} / \mathrm{kg}$ at $30-50$ $\mathrm{cm}, 5.18 \mathrm{mg} / \mathrm{kg}$ at $0-50 \mathrm{~cm}$, in $2011-3.22 ; 0.82 ; 2.26$ respectively, and in $2012-4.42$; $3.02 ; 3.86 \mathrm{mg} / \mathrm{kg}$ respectively; phosphorus in $2010-7.82 ; 1.22 ; 5.18$ respectively, in 2011 - $3.7 ; 2.2 ; 3.1$ respectively, and in $2012-15.0 ; 12.2 ; 13.8 \mathrm{mg} / \mathrm{kg}$ respectively; potassium in 
2010 - 200; 200; 200 respectively, in $2011-180 ; 140 ; 164$ respectively, and in 2012 - 140; $120 ; 132 \mathrm{mg} / \mathrm{kg}$.

When determining the amount of dry solids in the non-saline field at the beginning of the application period in 2010, the total dissolved solids (TDS) in the $0-70 \mathrm{~cm}$ layer was $0.227 \%$, chlorine ion $-0.015 \%$, sulphate $-0.105 \%$, in the $0-100 \mathrm{~cm}$ layer $-0.248 ; 0.016$; $0.105 \%$ respectively, and in a layer of $0-200 \mathrm{~cm}-0.242 ; 0.017$ and $0.123 \%$, respectively. In the weakly saline fields in 2010 , the amount of harmful salts in the $0-70 \mathrm{~cm}$ TDS was 0.370 , following chlorine ion $-0.035 \%$, and sulphate $-0.163 \%$, in the $0-100 \mathrm{~cm}$ layer $0.324 ; 0.037 ; 0.144 \%$ respectively, and in the $0-200 \mathrm{~cm}$ layer $-0.318 ; 0.033$ and $0.141 \%$ respectively. In the moderately saline fields in 2010, the amount of harmful salts from $0-70$ cm layer's total TDS was $0.528 \%$, following chlorine ion $-0.057 \%$, and sulphate $-0.292 \%$, at $0-100 \mathrm{~cm}-0.493 ; 0.065 ; 0.253 \%$ respectively, and in the $0-200 \mathrm{~cm}$ layer $-0.481 ; 0.077$; $0.230 \%$, respectively.

During the growing phases of Bukhara-102, the non-saline experimental field, where the groundwater level was 1.5-2.0 meters, was irrigated three times in 2010 with reference to the "0-2-1" irrigation system. The interval of irrigation was 24 days and the total irrigation water consumption within the growing season was $3400 \mathrm{~m}^{3} / \mathrm{ha}$. In 2011 , this field was irrigated four times following the "0-3-1" irrigation system. The interval of irrigation was ranging from 20 to 25 days and the total irrigation water consumption during the growing season was $4050 \mathrm{~m}^{3} / \mathrm{ha}$. In 2012, the non-saline field was irrigated three times according to the " $0-2-1$ " irrigation system. The irrigation interval was 27 days, and the total irrigation water consumption during the growing period was $3200 \mathrm{~m}^{3} / \mathrm{ha}$. Regarding the weakly saline cotton field, where all soil conditions were the same, but the depth of groundwater was lower (around 2.5-3.0 meters), was irrigated four times in 2010 in a "1-21 " irrigation system. Depending on the state of plant growth and development, the interval of irrigation was 25-26 days, and the total irrigation water consumption during the application period was $4000 \mathrm{~m}^{3} / \mathrm{ha}$. In 2011, the same field was irrigated field times in a " 1 $2-1$ " irrigation system. The irrigation interval was 24-26 days, and $4250 \mathrm{~m}^{3} /$ ha of irrigation water during the operation period was consumed. In 2012, this field was irrigated three times considering the " $0-2-1$ " irrigation system. The interval of irrigation was 25-30 days, and $3650 \mathrm{~m}^{3} /$ ha of irrigation water during the operation period was consumed. The total water consumption was required, while the depth of groundwater level was steeply low (around 2.5-3.0 m) depending on the growth and development status of cotton in the moderately saline field. In 2010, this field was irrigated four times following the "1-2-1" irrigation system. The interval of irrigation was $21-26$ days, and $4250 \mathrm{~m}^{3} /$ ha of water during the application period was used to irrigate. In 2011, the same field was irrigated four times through the same irrigation system. The irrigation water interval accounted for 18-23 days, and $4350 \mathrm{~m} 3 /$ ha of water during the operation period was consumed. In 2012, this field was irrigated three times in a "0-2-1" system. The interval between iterative irrigations was $25-$ 30 days, and the total irrigation water consumption constituted $3650 \mathrm{~m}^{3} /$ ha during the operation period.

In 2010, when tracking the growth and development status of cotton under the condition of applied fertilizers as N160P100K70 in the non-saline field, the following results were observed: the height of the main stem in I.VII was $67.6 \mathrm{~cm}$, in I.VIII $-99 \mathrm{~cm}$, in I.IX $99.7 \mathrm{~cm}$; yielding branches in accordance with the above 6.6; 12.8; 14.7 pieces respectively; the number of cotton cocoons was $8 ; 9 ; 14$ pieces, of which the number of bloomed pieces was $0 ; 3 ; 8$ pieces respectively. Under the condition of applied fertilizers as N190P130K90, the following results were observed: the height of the main stem in I.VII was $73.1 \mathrm{~cm}$, in I.VIII $-100.3 \mathrm{~cm}$, in I.IX $-102.1 \mathrm{~cm}$; yielding branches in accordance with the above $6.9 ; 14.6 ; 15.3$ pieces respectively; the number of cotton cocoons was $9 ; 7 ; 15$ pieces, of which the number of bloomed pieces was $0 ; 0 ; 3$ pieces respectively. When 
applying fertilizers as $\mathrm{N} 220 \mathrm{P} 160 \mathrm{~K} 110$, the following results were observed: the height of the main stem in I.VII was $78.4 \mathrm{~cm}$, in I.VIII $-102.7 \mathrm{~cm}$, in I.IX $-103.9 \mathrm{~cm}$; yielding branches in accordance with the above $7.3 ; 15.2 ; 16.0$ pieces respectively; the number of cotton cocoons was $10.1 ; 15.3$ pieces, of which the number of bloomed pieces was 2.5 pieces respectively.

In 2011, the above described process was iterated and followings were observed: under the condition of applied fertilizers as N160P100K70 in the non-saline field, the height of the main stem in I.VII was $47.4 \mathrm{~cm}$, in I.VIII $-73.4 \mathrm{~cm}$, in I.IX - $74.8 \mathrm{~cm}$; yielding branches in accordance with the above $7.5 ; 12.2 ; 13.2$ pieces respectively; the number of cotton cocoons was $7.9 ; 13.2$ pieces respectively, of which the number of bloomed pieces was 6.0 pieces. Under the condition of applied fertilizers as N190P130K90, the following results were observed: the height of the main stem in I.VII was $47.7 \mathrm{~cm}$, in I.VIII -76.9 $\mathrm{cm}$, in I.IX - $77.2 \mathrm{~cm}$; yielding branches in accordance with the above $7.7 ; 12.6 ; 13.9$ pieces respectively; the number of cotton cocoons was $8.9 ; 14.3$ pieces respectively, of which the number of bloomed pieces was 5.1 pieces. When applying fertilizers as N220P160K110, the following results were observed: the height of the main stem in I.VII was $47.9 \mathrm{~cm}$, in I.VIII - $78.9 \mathrm{~cm}$, in I.IX - $79.9 \mathrm{~cm}$; yielding branches in accordance with the above $7.9 ; 12.2 ; 13.8$ pieces respectively; the number of cotton cocoons was $8.5 ; 14.4$ pieces, of which the number of bloomed pieces was 3.7 pieces respectively.

During the experiment in 2010 on weakly salt-affected soils of the experimental field, with N160P100K70 ratio of fertilizers: the height of the main stem was $65.9 ; 95.0$; $95.9 \mathrm{~cm}$ respectively as above, yield branches - 5.7; 12.4; 14.1 pieces, and number of cocoons 8.2; 13.6, of which the number of bloomed cocoons was 4.0. With N190P130K90 of fertilizer application, the cotton growing and developing situation was intermediate. Lastly, with N220P160K110 of fertilizer ratio: the height of the main stem was 68.7; $100.2 ; 101.8 \mathrm{~cm}$ respectively, yield branches - 6.9; $15.0 ; 15.6$ pieces, and number of cocoons $9.5 ; 14.9$, of which the number of bloomed cocoons was 3.0.

Throughout the same experiment conducted in 2011 on weakly salt-affected soils of the experimental field, with N160P100K70 ratio of fertilizers: the height of the main stem was $46.2 ; 66.3 ; 69.4 \mathrm{~cm}$ respectively, yield branches $-7.1 ; 11.4 ; 12.9$ pieces, and number of cocoons $5.4 ; 12.2$, of which the number of bloomed cocoons was 6.9 . With N190P130K90 of fertilizer application, the height of the main stem was $46.3 ; 72.9 ; 74.2$ $\mathrm{cm}$ respectively, yield branches $-7.2 ; 12.0 ; 13.2$ pieces, and number of cocoons $6.7 ; 13.0$, of which the number of bloomed cocoons was 5.6. Last but not least, with N220P160K110 of fertilizer ratio: the height of the main stem was $49.5 ; 74.6 ; 76.7 \mathrm{~cm}$ respectively, yield branches $-7.4 ; 11.9 ; 13.1$ pieces, and number of cocoons $6.9 ; 13.3$, of which the number of bloomed cocoons was 4.1 .

Such experiment undertaken in the moderately saline cotton field in both experimental years resulted in as follows: in 2010, with N160P100K 70 , the height of the main stem was $56.6 ; 87.1 ; 90.0 \mathrm{~cm}$ respectively, yield branches - 5.2; 9.1; 12.9 pieces, and number of cocoons 6.1 ; 8.5, of which the number of bloomed cocoons was 4.3; with N190P130K90, the crop growth and development took an intermediate position; with N220P160K110, the height of the main stem was $69.9 ; 90.4 ; 93.7 \mathrm{~cm}$ respectively, yield branches - $6.0 ; 10.1$; 13.9 pieces, and number of cocoons $7.4 ; 11.5$, of which the number of bloomed cocoons was 3.7. The same patterns in 2011 were observed as follows: with N160P100K70, the height of the main stem was $38.4 ; 58.6 ; 64.8 \mathrm{~cm}$ respectively, yield branches - $6.5 ; 10.8$; 11.9 pieces, and number of cocoons $3.8 ; 8.3$, of which the number of bloomed cocoons was 7.5; with N190P130K90, the height of the main stem was 42.9; $64.8 ; 70.0 \mathrm{~cm}$ respectively, yield branches $-6.5 ; 10.8 ; 11.9$ pieces, and number of cocoons $3.8 ; 8.3$, of which the number of bloomed cocoons was 7.5; with N220P160K110, the height of the main stem 
was $69.9 ; 90.4 ; 93.7 \mathrm{~cm}$ respectively, yield branches $-8.1 ; 11.3 ; 12.7$ pieces, and number of cocoons 4.7 ; 11.0, of which the number of bloomed cocoons was 5.1.

From the above it can be recognized that the increase in the applied fertilizer standards, regardless of field conditions, had a positive effect on the growth and development of cotton, leading to a high cotton stem, high yielding branches, and a large number of (blooming) cotton cocoons.

When analyzing the state of cotton at different salinity levels, the highest growth and development rates were observed in the non-saline area, and the lowest biometric indicators were observed in the moderately saline areas. It was observed that the development of cotton in weakly saline areas took an intermediate position.

In 2010, in the second experiment carried out in the non-saline field, each cotton plant had 64.8 leaves with a wet weight of $170.2 \mathrm{~g}$, stem weight $-143.1 \mathrm{~g}$, and cocoon $-355.4 \mathrm{~g}$, and the total weight of a single cotton plant was equal to $674.1 \mathrm{~g}$. The surface of leafshore grew in the cotton constituted 4,906.5 $\mathrm{cm}^{2}$. During fertilization, in the moderately saline field, each cotton plant had 59.6 leaves with a wet weight of $159.8 \mathrm{~g}$, stem weight - $118.8 \mathrm{~g}$, and cocoon $-260.3 \mathrm{~g}$, and the total weight of a single cotton plant accounted for $543.8 \mathrm{~g}$. The surface of leafshore grew in the cotton outnumbered $4,628.6 \mathrm{~cm}^{2}$. In weakly saline fields, these indicators were observed to be intermediate under normal fertilizing conditions (Fig. 2).

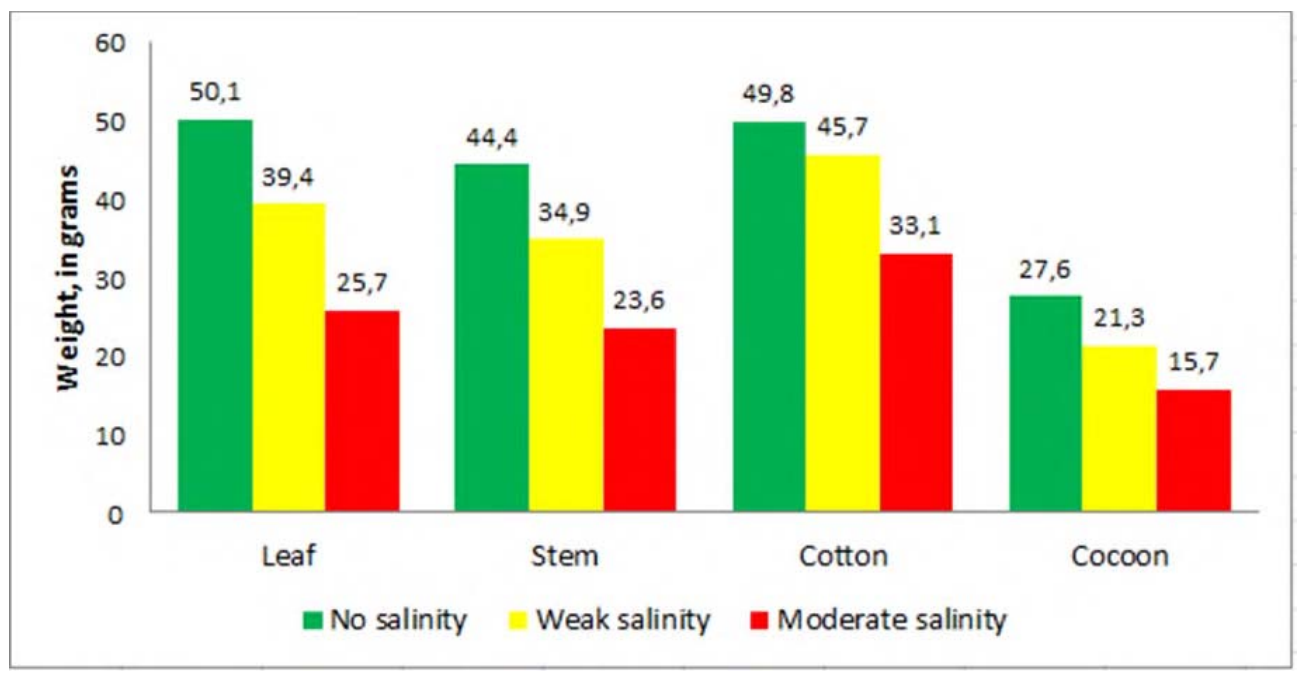

Fig. 2. Dry weight of cotton before maturation, in grams.

When comparing salinity levels, the heaviest cotton weight was observed in a nonsaline field of 7.20-7.24 g, and the lightest cotton weight was 6.37-6.43 $\mathrm{g}$ in a moderately saline field, regardless of fertilizing norms. The increase in mineral fertilizer application rate, compared to each other application rate as we discussed above, was determined by the proportional increase as a cotton weight heavier, the more heavier its cocoons. The maximum weight of one cotton cocoon was observed at all three salinity levels, 7.24; 6.72; $6.43 \mathrm{~g}$ respectively, during the season when fertilizers as N220P160K110 were applied in the field. The minimum one was discerned at all three salinity levels, $7.20 ; 6.63 ; 6.37 \mathrm{~g}$ respectively, during the season when fertilizers as N160P100K70 were applied in the field.

In 2011, when analyzing the amount of mineral fertilizers applied in the process of cotton cultivation, the highest yields, 45.8 quintals per ha, were obtained in the non-saline field from the second option of fertilizer application rate as N190P130K90, following in the weakly saline field -39.4 quintals per ha, and in the moderately saline fields -28.1 
quintals per ha. Unless N220P160K110 application amount of fertilizers improves the yield by $0.1 ; 0.6 ; 1.3$ quintals per ha respectively in differently salt-affected fields at three levels soil salinity levels, the calculation of additional yield in regards to fertilizer application rate was not mathematically proven in both, non-saline and weakly saline, fields, but increasing the amount of mineral fertilizers in the moderately saline field by N40P30K20 led to a slight increase in cotton yield (Fig. 3).

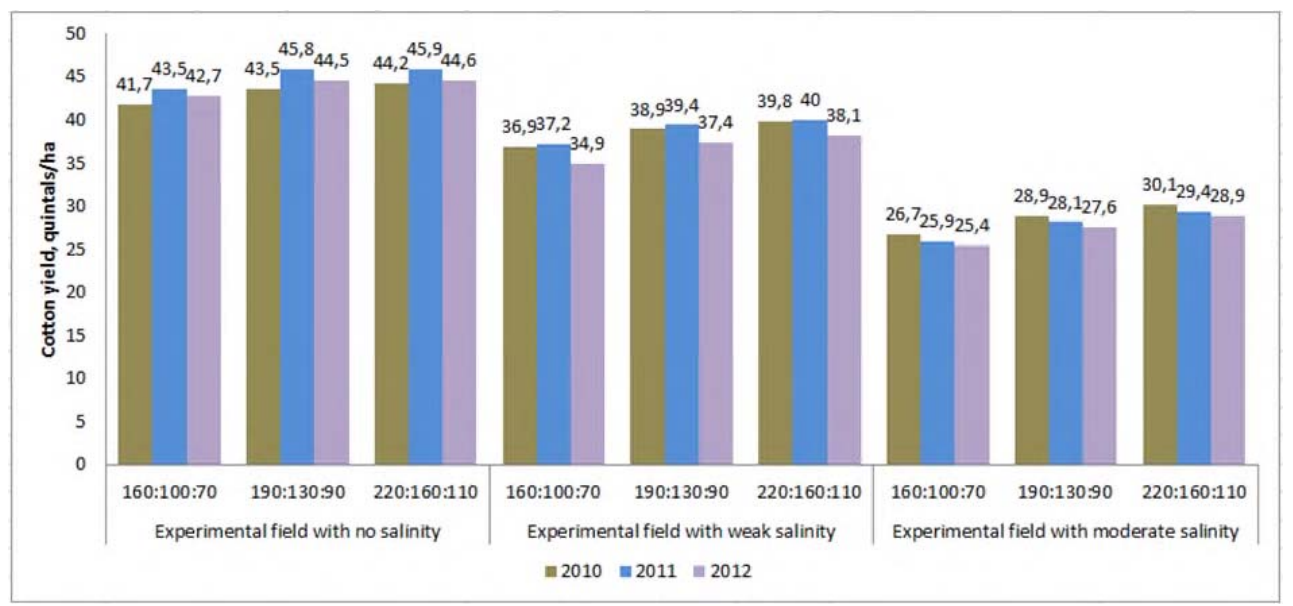

Fig. 3. Effect of mineral fertilizer application on cotton yield at three levels of soil salinity (20102012).

In 2012, the highest yields in the first harvest were 23.1-25.4 quintals/ha from nonsaline fields, 19.4- 19.7 quintals/ha from weakly saline fields, 15.3-16.2 quintals/ha from moderately saline fields. In the last harvest, the minimum yield weight was 3.2-5.9; $4.1-7.6 ; 2.1-4.3$ quintals/ha respectively corresponding to the soil salinity levels, and in the middle harvest, the yield amount took the intermediate place. Consequently, the total yield per hectare in all harvests was 42.7-44.6; 34.9-38.1; 25.4-28.9 quintals/ha corresponding to all soil salinity levels.

When the salinity levels were compared with each other, the average harvested gross yield, regardless of fertilizing norms, was 43.9 quintals/ha in the non-saline field, following 36.8 quintals/ha in the weakly saline field, and 27.3 quintals/ha in the moderately saline field.

The highest yields were harvested from the second option of fertilizer application (N220P160K110) which were 44.5 quintals/ha from the non-saline field, following 37.4 quintals/ha from weakly saline fields, and 27.6 quintals/ha from moderately saline fields. Unlike N220P160K110 application amount of fertilizers improves the yield by $0.1 ; 0.7 ; 1.3$ quintals per ha respectively in differently salt-affected fields at three levels soil salinity levels, the calculation of additional yield in regards to fertilizer application rate was not mathematically proven in both, non-saline and weakly saline, fields, but increasing the amount of mineral fertilizers in the moderately saline field by N40P30K20 led to a slight increase in cotton yield.

Below, we discussed and provided information on the economic efficiency of Bukhara102 grew on non-saline, weakly saline and moderately saline soils depending on fertilizer application standards, and irrigation, operational, and harvesting costs were taken into account. This was carried out depending on the irrigation technology used to calculate the cost-effectiveness of water-saving technologies.

Taking into account the results of economic efficiency, it became clear that in the conditions of overgrazed fallow non-saline soils, Bukhara-102 in the first option of 
fertilizer application standard, i.e. N160P100K70, brought conditional net profit - 961,026 $\mathrm{UZS} / \mathrm{ha}$ and a profitability rate of $55.1 \%$, following in the third option of fertilizer application, i.e. N220P160K110, conditional net profit was 958,589 UZS/ha, and a profitability rate of $50.6 \%$, which was 2,437 UZS less than in the first option of fertilizer application. In the weakly saline field, the first option brought the conditional net profit $460,913 \mathrm{UZS} / \mathrm{ha}$ and a profitability rate of $25.0 \%$, and the conditional net profit $-495,933$ $\mathrm{UZS} / \mathrm{ha}$ and a profitability rate of $24.8 \%$ was determined in the best fertilizer application standard, i.e. N220P160K110, which brought 35020 UZS more than the first option. In the moderately saline field, the conditional net profit in all options of fertilizer use was negative, forming a level of unprofitability.

Experiments have shown that the best economic performance is achieved in the second option of mineral fertilizer use (N190P130K90) among other two options of fertilizer application standards in cotton fields.

\section{Conclusions}

To ensure high and high-quality cotton yield of Bukhara-102 in the conditions of irrigated and saline soils of Kashkadarya province, following measures are highly recommended to perform:

(1) In order to reduce salt contents in soils with a groundwater level of 2.5-3.0 meters, to the non-saline field, $1,000 \mathrm{~m}^{3}$ per ha of water should be delivered to irrigate. In the case of weak salinity, once, regarding the moderate salinity, twice at the rate of $3,000 \mathrm{~m}^{3}$ and $4,130 \mathrm{~m}^{3}$ of water per ha should be delivered to leach salts;

(2) In the conditions of Bukhara-102 growing phases in non-saline cotton fields, N190P130K90 standard is highly encouraged to be applied. Breaking this fertilizer amount down into growing phases, applying P90K60 in pre-cultivation, N60 in leafing phase, $\mathrm{N} 70 \mathrm{~K} 30$ in mowing phase, and N60P40 in flowering phase is highly recommended;

(3) With respect to the Bukhara-102 growing phases in weakly and moderately saline cotton fields, N160P100K70 standard is highly encouraged to be applied. Breaking this fertilizer amount down into growing phases, applying P70K35 in pre-cultivation, N45 in leafing phase, N55K35 in mowing phase, and N60P30 in flowering phase is highly recommended.

This research was carried out within the framework of the fifth priority direction of the Republican Development of Science and Technology named 'Agriculture, Biotechnology, Ecology and Environmental Protection' and thanks to the heads of the 'Sunnatov Shahriyor' and 'Kurbanov Ilkhom Ismatillaevich' farm in the territory of "SH. Rashidov" Administrative Territorial Division (ATD) in "Kasbi" administrative district, Kashkadarya province for conducting this experiment.

\section{References}

1. Presidential Decree No. 5853 of the Republic of Uzbekistan on October 23, 2019, on "Measures for efficient use of land and water resources in agriculture"

2. Decree No 3405 Cabinet of Ministers of the Republic of Uzbekistan on November 27, 2017 , on the state program for the development of irrigation and improvement of reclamation of irrigated lands for 2018-2019

3. Presidential Decree No. 5742 of the Republic of Uzbekistan on July 19, 2019, on "Measures for efficient use of land and water resources in agriculture"

4. Methods of agrochemical, agrophysical and microbiological studies in irrigated lands, 439 (USSRCRI Press, Tashkent, 1963) (in Russian) 
5. Methods of agro-physical studies (Tashkent, 1973) (in Russian)

6. Methods of agro-chemical analysis of soil and plants (Tashkent, 1977) (in Russian)

7. Methods of conducting field experiments, 148 (Mekhnat Press, Tashkent, 2007) (in Uzbek)

8. Cotton - A reference book, 252 (Mehnat Press, Tashkent, 1989) (in Russian)

9. Reference of Cotton Production, 539 (Science and Technologies Press, Tashkent, 2016) (in Uzbek)

10. S. N. Rijov, Soviet Cotton, 6 (1940)

11. V. A. Kovda, 'Nauka' press, Moscow, 2, 29-47 (1973)

12. A. N. Kostyakov, Textbook (Selkhozgiz press, Moscow, 621, 1971)

13. S. A. Bezborodov, Selection, Seeding and Current Trends of Agrotechnology, 111-115 (2016)

14. N. F. Bespalov, S. N. Rijov, Bulletin of Agricultural Science, 2, 1-8 (1988)

15. SH. Mardiev, S. Isaev, International Journal of Research Culture Society (in press, accepten on June 25, 2019)

16. SH. Kenzhabaev, H. G. Frede, I. Begmatov, S. Isaev, B. Matyakubov, Journal of Critical Reviews, 7(5), 340-349 (2020)

17. S. Isaev, Z. Kadirov, K. Khamraev, B. Atamuratov, KH. Sanaev, Journal of Critical Reviews, 7(4), 354-360 (2020)

18. S. Isaev, A. Jumanov, M. Avlakulov, A. Tabaev, E. Malikov, Journal of Critical Reviews, 7(9), 251-257 (2020)

19. S. Isaev, I. Begmatov, G. Goziev, S. Khasanov, International Scientific Conference "Construction Mechanics, Hydraulics and Water Resources Engineering" (CONMECHYDRO-2020), 883(1), 012080 (2020)

20. S. Isaev, Y. R. Ashirov, U. T. Sultanov, Journal of Critical Reviews, 7(12), 173-178 (2020)

21. Climate data Retrieved from Uzhydromet info, on August 21, 2013

22. S. Isaev, S. Khasanov, Y. Ashirov, T. Karabaeva, A. Gofirov, E3S Web Conf., 244, 02012 (2021)

23. S. Isaev, S. Khasanov, Y. Ashirov, A. Gofirov, T. Karabaeva, E3S Web Conf., 244, 02047 (2021) 